\title{
GUTERRES, TIAGO DA COSTA. HERÓDOTO DE HALICARNASSO AUTORIA E ESCRITA DA HISTÓRIA. CURITIBA: PRISMAS, 2017. 176 P. ISBN: 978-85-5507-670-1.
}

Denis Renan Correa ${ }^{1}$

\section{Keywords}

Herodotus; History; authorship.

Tiago da Costa Guterres shows relevant contribution about a main aspect on Herodotus' work, that is, the authorial manifestation as an outstanding feature in ancient historiography. The book is a corrected and expanded version from his thesis concluded in 2012 when achieving the master's degree in History by UFRGS. The amendments made in the book are relevant because in the same year of this publication Guterres also concluded a PhD dissertation on the same subject of Herodotean authorial enunciation, but with a different focus. While in the doctoral dissertation he made in-depth approaches of Herodotus' pursuit for posterity, in the book here described the line of investigation is about Herodotus's differences with poetry when establishing his authorial presence within the pre-existing tradition. Despite of Guterres' kind of promise of minimizing explicative notes, as a way of not repelling the non-scholar reader, these notes are still long and numerous in the book. Guterres keep most of scholarship definition about concepts like "classical tradition" or "place of social production of discourses", discussions that could be shortened or even suppressed: the straightforward meaning of that concepts are clear to an outsider reader with no interest in rigorous scholarship. However, the writing does no harm to the fruition of reading, because fluent and well written prose follows us through the incursion in Herodotus' Histories. Guterres has established a solid research in this relevant subject not only to Ancient History, but also to History of Historiography, especially because of his competent and updated interface with studies about authorship and intellectual History.

The book's introduction draws an intellectual setting of the research: Foucault's idea of an "author function" has shaken this keystone of literary tradition and human knowledge. Concomitantly to a brief summary about modern studies on authorship, Guterres stresses the emergence of a notion of

\footnotetext{
${ }^{1}$ Assistant Professor - Federal University of Recôncavo da Bahia, Cruz das Almas, Brazil. E-mail: tecnocaos@gmail.com
} 
individuality in Greek though in the use of the word sphragis, that is, an authorial signature which an individual use to identify himself as a creator of a painting, a poem or a historical investigation. I shall stress two scholarship contributions to this subjects that are mentioned by Guterres. First, La Parola e il Marmo: Alle origini della poética greca from the Swedish scholar Jesper Svenbro (1984), that established the connection between the epigraphic sphragis and the poetical and historical signatures. With sphragis the ancient historian offers a monumental tone to his work that intends to persist through time by the imitation of epigraphic inscriptions, that is, he names himself in the third-person voice ("Herodotus of Halicarnassus shows his inquiry/ history...") and then slips out to the first-person voice. If Guterres approaches the subject of posterity only in another study, in this one he addresses the tension between the multiplicity of authorial voices: in the first line of the work he writes about himself in third-person, then through the narrative he will establishes many "voices" of "others" that Herodotus consulted and mentioned frequently, but at same time he distinguishes himself as authorial voice within the literary tradition. So, in drawing the multiplicity of voices in Herodotus' work, Guterres also mention the relevant contribution about enunciation theory from Problèmes de linguistique Générale (1976, or. 1966), also influent in Francois Hartog's Le Miroir d'Hérodote (1999, or. 1980). In Guterres' book these contributions on enunciation theory and Herodotus' work are decisive.

The first chapter "A Escrita da História: sobre a questão da autoria nas Histórias" states two points about the context of its main research concern: first, a brief summary on the reception of Herodotus' work though the centuries with a focus on its authorial presence, especially with Foucault's definition that authors hold accountability for that they have written, as happened to Herodotus. Then, Guterres approaches the main bibliographical contributions that ignores the role of authorship in Greek though, especially the so-called "School of Paris" with the head of Jean-Pierre Vernant, whose structuralist concerns ignored the subject of authorship or even the "self" as a main aspect of Greek though. However, the authorship of Herodotus does not remain an unexplored subject with the arrival of some scholars mentioned above, among others, who approaches the multiplicity of voices that composes the many forms of enunciation within the work.

In the second chapter, "Ser author na Grécia Antiga: da poesia inspirada ao desvio herodotiano", the keystone of the research is properly presented: Herodotus confronted a tradition in which the role of individuality, through the notion of sphragis, is stressed. So, Guterres approaches the authorial manifestations in Greek poets as Hesiod, Sapho and Pindar, in a section of the book that leaves some gaps which certainly he may explore in future studies. About 
his main thesis, Guterres shows the gradual evolution of sphragis as authorial manifestation: first related to the inspired song of the Muses from the poetic mindscape of the same period. Herodotus set himself as an intrusive narrator which manifest himself constantly within the narration using marks of enunciation which set hierarchies between many voices, not only your own, but voices from sources of information listened, evaluated and judged by the historian. That idea stress what Guterres call Herodotus authorial deviation from the poetic tradition. In his epistemological concept, the historical research replaces the divine inspiration in its authorial manifestation, so distinguishing itself from the poetic narration.

Once the premise about Herodotus authorial manifestation as a deviation from poetic authorship is properly established, Guterres' third chapter, "Heródoto e os poetas ou a construção do autor nas Histórias", is dedicated to the representation of poets within the text. The authorial manifestation is not only the sphragis and the first-person enunciations where Herodotus act as intrusive narrator, but also the difference he creates with "others", often criticizing many these authors, especially the poets and the logographer Hecataeus. Herodotus mention these authors both to criticize them or to reinforce some of his own arguments in the text. Guterres studies the mentions of Hecataeus, Homer, Hesiod, Archilochus, Aristeas, Aeschylus, Pindar and Solon. This examination of the Histories's contributes to our view about the differences that Herodotus makes between himself, logographers and poets under the sign of alterity, that is, everything "they" say is clearly different from what enunciates the "self" from the Herodotean author. However, it can't change the fact that Herodotus often mobilizes another author for his own purpose and in this game of identification and opposition Guterres shows how the text's authority is build up by the idea of rivalry among authors. Even if Herodotus mentions someone in a positive view, he can't help but ignore poetic versions about the Persian Wars, as we know from Pindar or Aeschylus. Herodotus makes a clear sign of alterity and distant from these poets when narrating these events, so he needs to ignore them to remark his distinct authorship.

This review cannot finish without saying something about the meaning of Herodotus' authorial manifestations within the wider modern historiographic tradition. Despite the distinction between ancient and modern way of doing it, the history that we practice today, and I mean all the debates and crisis of identity along, have a debt of patronage with ancient Greeks, especially Herodotus and Thucydides. Guterres' contribution is remarkable to remember how the notion of authorship, or the deviation that make the historian a narrator that enunciates in first-person voice (singular and personal for ancients, or plural and scholar for moderns) an investigation 
with multiple voices (or sources) that need to be evaluated and judged in its technical and ethical aspects. In a "pos-truth" haunted world, a problem not so strange for ancient Greeks, clarification of author(ship)'s role is fundamental for us to find again the meaning(s) of historical narrative. 